Protestantismo em Revista é licenciada sob uma Licença Creative Commons.

http://dx.doi.org/10.22351/nepp.v45i1.3111

\title{
ESPERANÇA ESCATOLÓGICA E ENGAJAMENTO: UMA LEITURA SÓCIO-POLÍTICA DE HEBREUS
}

\author{
Eschatological hope and engagement: a sociopolitical reading of Hebrews
}

Isaac Malheiros*

\begin{abstract}
Resumo:
Seguindo uma recente tendência nos estudos do Novo Testamento, este artigo fará, através da análise de textos bíblicos e da pesquisa bibliográfica, uma leitura sócio-política de Hebreus no contexto do Império Romano. Essa leitura faz emergir críticas cristãs mais ou menos veladas às reivindicações da Roma Imperial. Nessa leitura de Hebreus, cristaliza-se uma mensagem de resistência às alegações imperiais de uma cidade eterna e um imperador eterno, apresentando uma esperança melhor. Através desta pesquisa é possível concluir que Hebreus apresenta uma tensão entre a esperança escatológica de uma cidade celestial e o engajamento cristão nas questões da vida terrena, e que a mobilização cristã pode ser motivada e orientada pelos parâmetros teológicos encontrados em Hebreus..

Palavras-chave: Epístola aos Hebreus. Política. Religião. Leitura sóciopolítica.
\end{abstract}

\begin{abstract}
:
Following a recent trend in New Testament studies, this article makes a sociopolitical reading of Hebrews in its roman imperial context, through analysis of biblical texts and bibliographic research. This reading emerges veiled criticism to the claims of Rome. In this reading of Hebrews, there is a message of resistance against imperial claims of the eternal city and its eternal emperor, showing a better hope. Through this research it is possible to conclude that Hebrews presents a tension between the eschatological hope of a heavenly city and the Christian engagement with daily life, and that the Christian mobilization can be motivated and guided by theological parameters found in Hebrews.
\end{abstract}

Keywords: Epistle to the Hebrews. Politics. Religion. Sociopolitical reading.

* Doutor. Faculdades EST. E-mail: isaacmeira@gmail.com 


\section{Considerações iniciais}

Uma tendência recente nos estudos do Novo Testamento é a tentativa de analisálos mais especificamente no contexto do Império Romano. Nessa linha, Klaus Wengst ${ }^{1}$ fez $^{-}$ uma leitura provocativa de Hebreus, vendo ali uma mensagem anti-imperial velada e direcionada aos cristãos que viviam dentro das fronteiras do Império Romano.

Outros autores também têm tentado posicionar Hebreus como um documento antiimperial, ou pelo menos como um documento com veladas e esparsas críticas às reivindicações da Roma imperial. ${ }^{2}$ A pesquisa de Jason Whitlark ${ }^{3}$ foi uma das primeiras a tratar este tema de forma mais ampla.

Nessa leitura política de Hebreus, emerge uma mensagem de resistência às alegações imperiais de uma cidade eterna e um imperador eterno, apresentando uma esperança melhor. Apesar da leitura política de Hebreus ainda não ter tanta expressividade acadêmica, é uma leitura possível e com nuances políticas plausíveis em seus horizontes, e com interessantes aplicações contemporâneas, e por isso a tomaremos aqui como base. Este estudo não abordará as polêmicas questões introdutórias de Hebreus (autoria, data, etc.), mas partirá da pressuposição de que Hebreus foi uma palavra de motivação e exortação direcionada a um grupo de cristãos da segunda metade do primeiro século, a fim de que perseverassem em sua confissão e lealdade, e não abandonassem a fé em Cristo. ${ }^{4}$

\section{O evangelho imperial de César}

O culto ao imperador romano baseava-se na ideia de que o imperador era divino, senhor, filho de deus, salvador, cujo império tinha dimensões universais, e a quem se dedicavam altares e monumentos. Uma inscrição em um monumento dedicado ao

\footnotetext{
1 WENGST, Klaus. Pax romana: pretensão e realidade. São Paulo: Edições Paulinas, 1991.

2 Por exemplo, KOESTER, Craig R. Hebrews: A New Translation with Introduction and Commentary. New York: Doubleday, 2001. p. 72, 79, 297, 495-498, 577; PUNT, Jeremy. The Letter to the Hebrews. In: SEGOVIA, Ferdinand; SUGIRTHARAJAH, Sharada. (eds.). Postcolonial Commentary on the New Testament Writings. New York: Continuum, 2007. p. 338-368; DE SILVA, David A. Perseverance in Gratitude: A Socio-Rhetorical Commentary on the Epistle to the Hebrews. Grand Rapids: Eerdmans, 2000; AITKEN, Ellen Bradshaw. Portraying the Temple in Stone and Text: The Arch of Titus and the Epistle to the Hebrews. In GELARDINI, Gabriella (Ed.). Hebrews: Contemporary Methods. New Insights. Biblical Interpretation Series, vol 75. Boston: Brill, 2005. p. 131-148; JEWETT, Robert. Letter to Pilgrims: A Commentary on the Epistle to the Hebrews. New York: Pilgrim, 1981. p. 13-17; RÜPKE, Jörg. Starting sacrifice in the beyond Flavian innovations in the concept of priesthood and their repercussions in the treatise "To the Hebrews". Revue de l'histoire des religions, vol. 229, 2012, p. 5-30. Disponível em: <https://rhr.revues.org/7831\#text>. Acesso em: 09 set. 2016.

3 WHITLARK, Jason A. Resisting Empire: rethinking the purpose of the Letter to "the Hebrews". New York: Bloomsbury T\&T Clark, 2014.

${ }^{4}$ Diante da dificuldade de definir com precisão a autoria de Hebreus, nesta pesquisa o autor de Hebreus será identificado como "o Autor" ou "o autor de Hebreus".
} 
imperador Augusto César (Otávio Augusto), o primeiro imperador romano, na Ásia Menor ocidental (9 a.C.), revela a divinização do imperador e do império:

Todas as cidades adotam unanimemente o aniversário do divino César como o novo início do ano... Enquanto a Providência, que regulou toda a nossa existência... levou a nossa vida ao ápice da perfeição ao nos dar [o imperador] Augusto, a quem ela encheu de força para o bem-estar dos homens, e que sendo enviado a nós e a nossos descendentes como Salvador, pôs fim à guerra e colocou todas as coisas em ordem; e [por isso] tendo se tornado [deus] manifesto (phaneis), César realizou todas as esperanças de tempos anteriores... ao superar todos os benfeitores que o precederam... e enquanto, finalmente, o aniversário do deus [Augusto] se tornou para o mundo inteiro o começo de boas novas (euangelion) com relação a ele [portanto, que uma nova era comece a partir do seu nascimento]. ${ }^{5}$

Os romanos tinham uma consciência de que nasceram para dominar toda a terra e mar, e Augusto César foi descrito como aquele que "submeteu o universo ao domínio do povo romano". ${ }^{6}$ No primeiro século d.C., Roma e seu imperador receberam contornos de eternidade e invencibilidade. De acordo com a leitura do Novo Testamento no contexto imperial, os primeiros cristãos protestaram veladamente contra o império, comparando Jesus a César e apontando a superioridade de Cristo. ${ }^{7}$ Assim, contrapondo-se ao domínio universal do império, Hebreus 1 e 2 mostra a exaltação de Jesus sobre tudo e todos.

No ano 112 d.C., Plínio, o Jovem (ou Plínio II), então governador romano da Bitínia, na Ásia Menor, afirmou em carta ao imperador Trajano que os cristãos rejeitavam o culto ao imperador, mas sempre se reuniam para cantar hinos a "Cristo como a um Deus". ${ }^{8}$ Essa repulsa cristã ao culto imperial perpassa sutilmente todo o Novo Testamento.

Se no mundo imperial já havia um salvador divino, um senhor que havia trazido paz e salvação para a humanidade e a quem cultuavam com festas e hinos, ao aplicar esses termos a Jesus, os cristãos estavam sendo subversivos: "agem contra os decretos de César, afirmando que há outro rei, Jesus"' (At 17.7).

No culto imperial, o imperador era adorado como um deus não apenas por questões religiosas, mas também em troca de honras imperiais, benefícios fiscais e segurança. No entanto, como outras tentativas utópicas registradas na história, a Pax Romana ${ }^{9}$ foi uma paz imposta, de cima para baixo. Dentre os antigos, Tácito se opõe à glorificação da Pax Romana: "sem dúvida, paz; mas paz toda manchada de sangue". ${ }^{10}$ Os conquistados que se negavam

\footnotetext{
${ }^{5}$ HORSLEY, Richard A. O reino de Deus e a nova desordem mundial. São Paulo: Paulus, 2004. p. 29

${ }^{6}$ WENGST, 1991, p. 24.

7 Para mais comparações entre Cristo e César, ver NEWTON, Bert. Subversive Wisdom: Sociopolitical Dimensions of John's Gospel. Eugene: Wipf \& Stock, 2012. p. 9-25.

${ }^{8}$ Pliny the Younger. Disponível em: <http:/ / www.earlychristianwritings.com/text/pliny.html>. Acesso em: 10 set. 2016.

${ }^{9}$ Esta expressão latina é usada para indicar, relativamente, o período do Império Romano entre o reinado de Augusto César (29 a.C., quando ele deu fim à guerra) e a morte de Marco Aurélio (no ano 180 d.C.). No entanto, a Pax Romana é mais que um período histórico. É uma ideologia, um projeto de poder que envolvia ações políticas e militares, que garantia estabilidade ao império, submissão ao imperador, e mascarava o sistema de exploração e violência existentes no Império.

10 WENGST, 1991, p. 20.
} 
a ver Augusto como um salvador, o príncipe da paz, e até mesmo um filho de deus, sofriam terríveis perdas, eram pilhados, mortos, reduzidos à escravidão ou sufocados com impostos. Qualquer um que não fosse cidadão romano e ameaçasse a Pax Romana estaria sujeito a ser condenado à vergonhosa morte por crucificação.

Religião e política no império romano eram inseparáveis. Além de divino, o imperador também era sacerdote supremo, o pontífice máximo (do latim Pontifex Maximus). Nesse contexto de um imperador-sacerdote, Hebreus apresenta Jesus como rei-sacerdote, o sumo sacerdote $(\mathrm{Hb}$ 6.20; 7.1-3; cf. $\mathrm{Hb} 1.3-13 ; 8.1 ; 10.12 ; 12.2)$. Além de outro rei, a comunidade cristã tem um reino bem definido, com trono e cetro ( $\mathrm{Hb} 1.8 ; 4.16 ; 12.28)$.

\section{A idolatria e o messianismo político}

Por muito tempo, prevaleceu entre os estudiosos do Novo Testamento a ideia de que a Pax Romana foi benéfica à igreja primitiva, possibilitando-lhe o florescimento por causa das condições pacíficas entre as províncias, pela construção de estradas, e pela falta de interesse do Império Romano neste novo movimento religioso. Mas tal ideia tem sido paulatinamente abandonada à luz dos estudos mais recentes, e a leitura política de Hebreus reflete o lado sombrio da Pax Romana.

O império romano oferecia um duplo risco à fé cristã: a perseguição e a sedução. Usando como parâmetro a leitura política de Hebreus proposta por Whitlark, ${ }^{11}$ é possível afirmar que os destinatários de Hebreus estavam em perigo de abandonar a fé em Jesus por causa tanto da perseguição opressora quanto por causa das atrações de uma tentadora cultura impregnada de idolatria. Em Hebreus, o tema da idolatria é sutilmente abordado através de referências ao "Deus vivo" (Hb 3.12; 10.31; 12.22), às “obras mortas" (Hb 6.1; 9.14), e a eventos narrados no Antigo Testamento.

A Pax Romana estava diretamente ligada à pessoa do imperador. Sêneca usa a expressão Pax Romana pela primeira vez falando da vida do imperador como a condição para a manutenção da paz: "Enquanto o rei permanece com vida, todos permanecem unânimes, se ele [o rei] for perdido, eles [o povo] quebram a fidelidade. Esta desgraça será o fim da paz romana [pax romana], isto fará cair em ruínas a felicidade de tão grande povo". ${ }^{12}$

Havia, mesmo entre os judeus, grupos que apoiavam Roma, movidos por diversos interesses (os herodianos e os saduceus, por exemplo). O imperador, mais que um homem poderoso, era um símbolo catalisador de expectativas e afeições. Ele representava uma ideologia, a esperança de um mundo novo, melhor, mais seguro, a Pax Romana.

11 WHITLARK, 2014.

12 SÊNECA, apud WENGST, 1991, p. 18. 
Nesse contexto histórico, em que participar do culto imperial era um importante método para garantir mobilidade social e segurança, ${ }^{13}$ Hebreus já começa expondo o dever cristão de adorar a Cristo, e não criaturas como os anjos (Hb 1:8-14).

O modo de viver Romano se espalhou na Pax Romana. A vida em cidades era uma característica essencial, o sonho de consumo que seduzia boa parte da população. ${ }^{14} \mathrm{~A}$ urbanização garantiu a construção de templos, praças públicas, casas, pórticos, banhos, banquetes, oficinas e escolas (para os nobres). ${ }^{15}$

Tudo isso se tornou elemento de escravização cultural. Se antes, os subjugados negavam a língua romana, agora eles querem aprender a retórica romana, e até usar a toga romana no vestuário. Os jogos também eram um instrumento político para assegurar a paz e a dominação cultural, "cuidar da alegria e da boa disposição". ${ }^{16}$ Com as lutas de gladiadores, com animais e com a distribuição gratuita de cereais, Roma alcançou "mais junto aos subjugados do que por suas armas!", 17 protestou um germano. Assim, a imagem divina do imperador se consolidava.

$\mathrm{O}$ autor de Hebreus tinha a mente imersa no Antigo Testamento: toda a sua argumentação é feita usando alusões ao Antigo Testamento como pano de fundo, citando, resumindo, parafraseando ou insinuando de alguma forma. ${ }^{18} \mathrm{E}$ a Bíblia hebraica frequentemente alerta sobre os perigos de se depositar a confiança política em modelos humanos: "Não confieis em príncipes, nem nos filhos dos homens, em quem não há salvação. Quando lhes sai o espírito, eles voltam ao pó; nesse mesmo dia cessam todos os seus planos" (Sl 146.3-4). E, por outra via: "É melhor confiar no Senhor do que confiar no homem. É melhor confiar no Senhor do que confiar nos príncipes" (Sl 118.8-9).

O autor de Hebreus traz à tona o tema da idolatria também ao citar Abraão e os patriarcas. Abraão havia sido tirado da terra de seus pais e antepassados, que "adoravam a outros deuses" (Js 24:2), os "deuses da terra" (Dt 31:16), que seriam adorados na própria terra prometida. Há um vínculo entre os deuses e a terra, entre a idolatria e as nações. Abraão, como o pai da fé, ensina aos cristãos que é preciso superar a idolatria dos deuses da terra. A idolatria ataca os direitos exclusivos de Deus à suprema afeição, confiança e obediência.

A tentação da idolatria é multifacetada e sempre presente. As pessoas imaginam ser beneficiadas por ideologias e líderes aparentemente beneficentes, que lhes concedem

\footnotetext{
${ }^{13}$ WHITLARK, 2014, p. 56.

14 SENNETT, Richard. Carne e pedra: o corpo e a cidade na civilização ocidental. Rio de Janeiro: Record, 1997. p. 87.

15 SAVELLE, Max. História da civilização mundial: as primeiras culturas humanas. Belo Horizonte: Itatiaia, 1971. p. 301.

16 WENGST, 1991, p. 65.

17 WENGST, 1991 p. 66.

${ }_{18}$ GUTHRIE, Donald. Hebreus: introdução e comentário. Série Cultura Bíblica. São Paulo: Vida Nova e Mundo Cristão, 1984. p. 35-36; DOCHERTY, Susan. The use of the Old Testament in Hebrews: a case study in early Jewish Bible interpretation. Tübingen: Mohr Siebeck, 2009. p. 121; WILSON, R. McL. Hebrews. The New Century Bible Commentary. Grand Rapids: Eerdmans, 1987. p. 19; 27.
} 
benefícios e proteção em troca de fidelidade. ${ }^{19}$ Como na época do culto ao imperador, o amor, a confiança e a obediência do cristão de outras épocas podem ser direcionados a ideologias e movimentos acima de Deus, constituindo-se em idolatria. Keller alerta:

Uma ideologia, assim como um ídolo, é uma descrição parcial e limitada da realidade que foi promovida ao nível da palavra final sobre as coisas. Ideólogos acreditam que a sua escola ou partido têm a resposta real e completa para os problemas da sociedade. ${ }^{20}$

Comparando a idolatria dos tempos bíblicos com a idolatria contemporânea, Koyzis também destaca as ideologias:

Nelas [nas ideologias], um elemento extraído da criação divina é transformado em uma espécie de deus capaz de nos salvar. Em seu apogeu, a ideologia parece invencível e oferece certa ilusão de veracidade abrangente baseada em pontos que de fato são verdadeiros, sendo aceita por milhões de pessoas. Com o tempo, no entanto, a ideologia perde sua vitalidade e passa a ter menos adeptos, em certa medida por não ter conseguido cumprir suas promessas, mas também porque suas contradições se manifestaram, tornando-a inviável. ${ }^{21}$

No contexto imperial, havia o risco dos objetivos ideológicos da Pax Romana e do culto ao imperador tornarem-se concorrentes com a soteriologia cristã, e o autor de Hebreus deixa claro que a salvação vem através de Cristo e seu trono de graça ( $\mathrm{Hb} 4.16$; 5.9; 7.25; 9.28). Aceitar o imperador e sua Pax Romana como a grande opção redentora poderia caracterizar idolatria, como define Dooyeweerd:

A essência de um espírito idólatra é que ele separa o coração do homem do Deus verdadeiro e, em lugar de Deus, coloca uma criatura. Toda absolutização do que é relativo aponta para a deificação do que foi criado. Considera-se autossuficiente o que não é autossuficiente. ${ }^{22}$

Além do contexto do culto ao imperador, nesse mesmo período de idolatria política em que Hebreus foi escrito, muitos movimentos messiânicos surgiam sucessivamente entre os judeus. ${ }^{23}$ De fato, a opressão sempre tende a gerar esperança messiânica. Mas o conteúdo de Hebreus afirma que, para os cristãos, o Messias já havia chegado, enfatizando Cristo como o divino rei-sacerdote do novo reino e da nova cidade celestial.

\footnotetext{
${ }^{19}$ Esse tema é tratado com mais profundidade em FERREIRA, Franklin. Contra a idolatria do Estado: o papel do cristão na política. São Paulo: Vida Nova, 2016.

${ }^{20}$ KELLER, Timothy. Counterfeit Gods: The Empty Promises of Money, Sex, and Power, and the Only Hope That Matters. New York: Dutton, 2009. p. 104.

${ }^{21}$ KOYZIS, David. Visões e Ilusões Políticas. São Paulo: Vida Nova, 2014. p. 50-51.

22 DOOYEWEERD, Herman. Raízes da cultura ocidental: as opções cristã, secular e pagã. São Paulo: Cultura Cristã, 2015. p. 29.

${ }^{23}$ As revoltas judaicas contra o Império Romano, do séc. I a.C. ao séc. II. d.C., incluíam em suas motivações as expectativas messiânico-apocalípticas. Ver MESTERS, Carlos. Los Profetas Juan y Jesús y otros líderes populares de aquella época. Revista de Interpretación Bíblica Latino-Americana, San José, n. 1, (p. 45-52), 1988. p. $46-50$.
} 


\section{As alegações com implicações políticas de Hebreus}

Jesus, e não César, é o eterno rei em Hebreus. Seu reinado e domínio eterno são afirmados com sua ascensão e entronização (Hb 1.5-13). Ele ressuscitou (Hb 13.20) para uma existência eterna, a "melhor ressurreição" (Hb 11.35), também aguardada pelo povo de Deus. Ele "permanecerá" (Hb 1.11), e seus anos "não acabarão" (Hb 1.12). Ele foi entronizado no "mundo futuro" ( $\mathrm{Hb} 2.5$ ), sem nenhuma ameaça ao seu governo eterno. Mas nada disso aconteceu como na apoteose pós-morte dos imperadores romanos: Cristo já era criador de todas as coisas e herdeiro do universo, o resplendor da glória e a expressão exata da divindade, "sustentando todas as coisas pela palavra do seu poder" (Hb 1.2-3).

A exaltação de Cristo não se dá pela apoteose póstuma, mas porque ele possui uma "vida indestrutível" ( $\mathrm{Hb} 7.15)$, não é "impedido de permanecer" pela morte (Hb 7.23), mas "permanece eternamente" (Hb 7.24) e vive sempre (Hb 7.25). Ele "é o mesmo, ontem, hoje e para sempre" (Hb 13.8). Roma não assegurou, e nem sequer prometeu, a participação eterna do povo em seu reino, como Jesus fez (Hb 12.22-24).

Por isso, quando a igreja primitiva, especialmente Paulo, usava termos gregos como ekklēsia (igreja), euangelion (evangelho), pistis (fé), dikaiosyne (justiça), eirene (paz), e kyrios (senhor), isso poderia soar como um desafio direto à ideologia política romana, que também utilizava esses termos, mas com sentidos políticos. Horsley argumenta que Paulo apresentou seu evangelho como um concorrente direto do evangelho de César e do evangelho imperial da salvação. ${ }^{24}$

Augusto e seus sucessores já haviam anunciado o euangelion da soteria (salvação) do imperador. Agora, surgem os cristãos proclamando o euangelion de Jesus como o verdadeiro Kyrios (Senhor) e Soter (Salvador). A eirene (paz) de Cristo teria sido entendida também como um desafio à Pax Romana e à dikaiosyne (justiça) dos kyrios romanos. Em suma, há no cristianismo, no mínimo, uma linguagem de resistência ao império romano.

Crossan afirma que o uso desses termos não é "apenas uma série de coincidências acidentais" ${ }^{25}$ Ele complementa:

Esse paralelismo fundamental é, portanto, antagonismo profundo: dois programas escatológicos que se chocam um com o outro. $\mathrm{O}$ cristianismo sabia disso desde o início e de maneira clara. Roma sabia disso desde o início, mas de maneira obscura" ${ }^{26}$

\footnotetext{
${ }^{24}$ HORSLEY, Richard A. Paulo e o império: religião e poder na sociedade imperial romana. São Paulo, SP: Paulus, 2004. p. 141-247.

${ }^{25}$ CROSSAN, John Dominic. O nascimento do cristianismo: o que aconteceu nos anos que se seguiram à execução de Jesus. São Paulo: Paulinas, 2004. p. 450.

${ }^{26}$ CROSSAN, 2004, p. 451.
} 


\section{As cidades de Hebreus}

Hebreus contrapõe duas cidades: 1) a cidade com fundamentos, construída por Deus, Jerusalém celestial que há de vir ( $\mathrm{Hb} \mathrm{11.10,} \mathrm{16;} \mathrm{12.22);} \mathrm{e} \mathrm{2)} \mathrm{a} \mathrm{"cidade} \mathrm{permanente",} \mathrm{de}$ $\mathrm{Hb}$ 13.14. Poucos comentaristas arriscaram um palpite categórico sobre a identificação da segunda cidade, pois essa declaração é aplicável a qualquer cidade. ${ }^{27}$ Mas, se tomado como uma crítica, como sugere Whitlark, $\mathrm{Hb}$ 13.14a deve estar fazendo uma referência específica a uma cidade sobre a qual havia uma expectativa de durar para sempre. Historicamente, no contexto de Hebreus, Roma era a cidade sobre a qual tal alegação era aplicada.

Roma era conhecida como cidade eterna, e os poetas prediziam que ela jamais teria fim. ${ }^{28}$ A literatura romana, bem como as inscrições em moedas e monumentos da época, repetidamente afirmavam que Roma duraria para sempre, era cidade eterna cujo poder nunca teria fim, o que levou alguns autores a acreditarem que Hb 13.14 é uma crítica velada ao império romano e à alegação da perpétua existência de Roma. ${ }^{29}$

Outros autores, porém, acham que a cidade referida é Jerusalém. ${ }^{30}$ De fato, a tradição pré-exílica retrata Jerusalém/Sião como eterna, mas a tradição pós-exílica não descreve a Jerusalém reconstruída como uma cidade eterna. Em vez disso, a tradição judaica, consolidada na literatura apocalíptica, apontava para uma nova Jerusalém, celestial, como a cidade eterna que se manifestará no final da história (Jr 31.38-40; Ez 8-10; 43; 2Bar 4.3; 32.24; 4Esdras 7.26; 10.27, 47; 13.36; Ap 21.2; e outros). Hebreus também apresenta essa esperança judaica sobre a cidade celestial, a nova Jerusalém. Assim, Jerusalém como a cidade eterna era uma esperança futura, não uma presente realidade, e Roma parece ser uma melhor opção.

A cidade celestial recebeu destaque nos capítulos 11 e 12 (Hb 11.10, 16; 12.22), onde o caráter espiritual da comunidade é ressaltado: os patriarcas esperavam por tal cidade construída por Deus (Hb 11.10, 16). Por mais que se empenhe em edificar cidades, sociedades, comunidades, o cristão está consciente de que o caráter durável de sua cidade está no futuro, não nas circunstâncias presentes. Essa crítica final à cidade eterna soma-se ao tema da superioridade do reino sacerdotal de Cristo para sugerir a incapacidade do império romano de garantir a eternidade da cidade imperial. A comunidade cristã já tem um rei que assegura o acesso à verdadeira cidade eterna.

Nessa leitura política, Hebreus apresenta um conteúdo de resistência à ilusão do império terreno eterno, seja Roma, Jerusalém ou qualquer outra cidade eterna. As falsas expectativas e sonhos utópicos em torno de projetos políticos de poder não deveriam levar o cristão a esquecer que: "Por mais permanentes que as cidades feitas pelos homens pareçam

\footnotetext{
27 Ver WHITLARK, 2014, p. 102, nota 12.

28 Sobre esse tema, ver WHITLARK, 2014, p. 100-121.

29 WENGST, 1991, p. 142; WHITLARK, 2014, p. 115.

30 Ver WHITLARK, 2014, p. 103, nota 15.
} 
ser, o mundo tem espalhado pela sua superfície os remanescentes de comunidades que outrora eram poderosas". 31

Esse contraste com Roma é sutil, mas o contraste com as tendas dos patriarcas é mais explícito. A cidade eterna aguardada tem fundamentos ( $\mathrm{Hb} 11.10)$, enquanto as tendas ( $\mathrm{Hb}$ 11.9) em que os patriarcas habitaram não possuíam fundamentos. Nesse contraste entre as tendas e a cidade que tem fundamentos, os fundamentos podem denotar permanência e estabilidade. ${ }^{32} \mathrm{O}$ cristão possui uma fé que vê permanência e estabilidade na esperança escatológica.

Em Hebreus, a esperança escatológica cristã inspira-se em pessoas peregrinas como Abraão, cuja permanência em Canaã foi tão temporária quanto suas tendas, mas cuja fé foi permanente, projetando-se para além da promessa de uma terra. ${ }^{33}$

\section{Peregrinação terrena e cidadania celestial}

Os patriarcas eram "estrangeiros [em grego, xénos, forasteiro, desconhecido, dessa raiz vem a expressão xenofobia] e peregrinos [parepidémos, residentes temporários, exilados, mais forasteiros de passagem que estrangeiros residentes] sobre a terra" (Hb 11.13). Mesmo na terra prometida, eles continuaram "procurando uma pátria" (Hb 11.14). Ao descrever os heróis da fé, Hebreus afirma que eles "andaram peregrinos" (Hb 11.37), de lugar em lugar.

Os termos gregos utilizados indicam que o peregrino em Hebreus pode até ter residência fixa, habitar na terra, mas não o faz como dono legítimo, ou como pertencente àquela pátria, e sim como um estrangeiro. ${ }^{34}$ Essa existência nômade, destacada em Hebreus no fato de habitarem em tendas, não é definida pelo tempo de permanência geográfica, mas sim pela esperança escatológica de morar na cidade eterna, numa pátria melhor ( $\mathrm{Hb} 11.16)$. Eles poderiam ter passado a vida inteira morando num mesmo lugar, mas continuariam sendo peregrinos.

A palavra pátria (patrís), de uso raro tanto na Septuaginta quanto no Novo Testamento, $^{35}$ não se refere apenas a um lugar para habitar, mas a uma pátria onde uma nação pode encontrar suas raízes, com significados históricos. ${ }^{36}$ Os cristãos têm suas nacionalidades, mas suas raízes mais profundas não estão aqui, e são lembrados em Hebreus de que há outro Rei, outro Reino, outra Pátria, e outra Cidade.

Mas o que é a pátria superior dos cristãos? Ela é claramente identificada como sendo celestial (Hb 11.16). O celestial é um tema característico de Hebreus: fala da vocação celestial

\footnotetext{
31 GUTHRIE, 1984, p. 257.

32 GUTHRIE, 1984, p. 218.

33 KISTEMAKER, Simon J. Comentario al Nuevo Testamento. Grand Rapids: Libros Desafío, 1991. p. 378.

${ }^{34}$ GUTHRIE, 1984, p. 217.

35 GUTHRIE, 1984, p. 219.

36 GUTHRIE, 1984, p. 220.
} 
( $\mathrm{Hb} 3.1)$, do dom celestial $(\mathrm{Hb} 6.4)$, do santuário celestial $(\mathrm{Hb} 8.5)$, das coisas celestiais $(\mathrm{Hb}$ 9.23), da pátria celestial ( $\mathrm{Hb} 11.16)$ e da Jerusalém celestial (Hb 12.22). E o céu é o lugar onde Cristo ministra e é exaltado para sempre ( $\mathrm{Hb} 7.8 ; 8.1 ; 9.24)$.

O Novo Testamento ensina que “a nossa cidadania está nos céus” (Fp 3.20). A expressão grega para cidadania (políteuma) refere-se à comunidade, ao estado; portanto, $\mathrm{o}$ cristão pode afirmar que o seu Estado está nos céus. Jesus estabeleceu esse conceito ao declarar que "o Meu reino não é deste mundo" (Jo 18.36), e Paulo afirma que "somos embaixadores em nome de Cristo" (2Co 5.20). Como afirmou Calvino, comentando esse tema, "não haverá lugar para nós entre os filhos de Deus, a menos que renunciemos ao mundo; e que não haverá herança no céu para nós, a menos que sejamos peregrinos sobre a terra". 37

A própria galeria dos heróis em Hebreus 11 desnacionaliza a história bíblica, pois a principal característica no perfil dos heróis selecionados nesse capítulo é a marginalização em relação à nação de Israel, criando uma linhagem bíblica sem se prender à identidade nacional, uma linhagem aberta aos fieis em geral. ${ }^{38}$ Ou seja, Hebreus 11 transforma o status de heróis nacionais em status de fiéis na condição de marginalizados. Por isso, esses heróis são exemplos inspiradores para os cristãos também marginalizados, sem pátria aqui.

Mas como deve viver o cristão peregrino, sem pátria e cidadão do céu? Deve viver apenas na expectativa escatológica, sem nenhum envolvimento com as questões terrenas?

\section{Cidadãos do céu atuantes na terra: os deveres sociais}

Apesar da cidadania celestial, os cristãos não vivem num mundo etéreo, afastados dos dilemas da vida diária. O chamado para "sair do arraial" (Hb 13.13) não significa afastamento do convívio coletivo, como veremos. Em Hebreus, o cristão é um peregrino, um estrangeiro num êxodo em direção ao descanso de Deus e à cidade celestial, mas não é um separatista alienado. Os cristãos estão peregrinando entre o aqui/agora e o que virá, mas não se excluem de um mundo que não é mais digno deles (Hb 11.38). Como "sal da terra" e "luz do mundo" (Mt 5.13-14), são embaixadores de Cristo (2Co 5.20), representantes do Reino. No entanto, estão plenamente conscientes da brevidade da vida e da natureza passageira deste mundo, desejando a cidade "que há de vir" (Hb 13.14). ${ }^{39}$

A esperança escatológica não paralisa a atuação cristã como sal da terra e luz do mundo, antes, é um fator motivador. A redenção em Cristo Jesus tem como implicação principal a justiça sendo manifesta no aspecto social e político, partindo do indivíduo e da cooperação fraternal da comunidade cristã. Hebreus exige que os cristãos vivam em "amor

\footnotetext{
37 CALVINO, Juan. Epístola a los Hebreos. Grand Rapids: SLC, 1977. p. 248.

38 BEALE, G. K.; CARSON, D. A. Comentário do uso do Antigo Testamento no Novo Testamento. São Paulo: Vida Nova, 2014. p. 1207-1208.

39 KISTEMAKER, 1991, p. 386.
} 


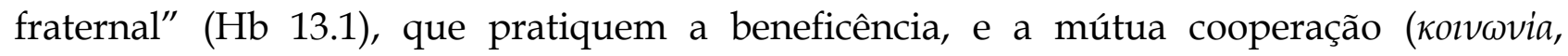
contribuição, generosidade, partilha) ( $\mathrm{Hb} 13.16)$.

Além disso, eles devem praticar a hospitalidade (filoxenía, literalmente "amor aos estrangeiros") (Hb 13.2), o acolhimento sem lugar para xenofobia e nacionalismos. $\mathrm{Na}$ época, havia muitos que precisavam de hospedagem: escravos que não tinham casa própria, pregadores itinerantes, irmãos tinham que viajar a negócios. Muitas hospedarias e pousadas eram caras, sujas e de má fama. ${ }^{40} \mathrm{O}$ texto estabelece um princípio permanente: o cristianismo era, e de acordo com Hebreus ainda deveria ser, uma religião de portas abertas.

Em Hebreus, os cristãos são elogiados porque "se compadeceram [sympathéō] dos que estavam na prisão" (Hb 10.34a), e com as vítimas de maus tratos (Hb 13.3). Essa simpatia, essa identificação com o sentimento e a dor dos que estão encarcerados, é da mesma espécie da simpatia que Cristo manifesta pelos pecadores em $\mathrm{Hb} 4.15$. O próprio Jesus deu importância ao atendimento dos detentos, incluindo tal atividade como um dos critérios considerados no julgamento final (Mt 25.36).

Há testemunhas históricas do cuidado dos cristãos dos primeiros séculos pelo aprisionados. Aristides de Atenas, um autor do século II, escreveu que quando os cristãos “ouvem que um deles está preso ou que sofre por causa do nome do seu Messias, todos eles ansiosamente ministram à sua necessidade, e se é possível resgatá-lo, eles o libertam" ${ }^{41} \mathrm{~A}$ obra Constituições dos Santos Apóstolos, provavelmente do terceiro século, ${ }^{42}$ recomenda que o dinheiro ganho com o trabalho honrado dos cristãos seja usado para "a redenção dos santos, a libertação dos escravos e dos cativos, e dos prisioneiros, e daqueles que foram abusados, e daqueles que foram condenados por tiranos para um combate e morte por causa do nome de Cristo" (Constituições dos Santos Apóstolos 4.1.9). ${ }^{43}$

Certamente, $\mathrm{Hb} 13.3$ inclui temas atuais como a pastoral carcerária, os direitos humanos, a violência doméstica e infantil, dentre outros. O texto é uma aplicação da regra de ouro (Mt 7.12), e não orienta o cristão a perguntar se os que sofrem adversidades merecem ou não ajuda; para que o cristão se envolva, é suficiente que haja a necessidade de ajuda.

Outro dever cristão em Hebreus é a manutenção da pureza sexual, e a valorização do casamento "entre todos" (Hb 13.4). No contexto do império romano, a idolatria também estava associada à imoralidade sexual. ${ }^{44} \mathrm{O}$ Antigo Testamento usa abundantemente a imoralidade sexual como metáfora para a infidelidade espiritual e a idolatria (por ex., Ez 16; 23; Os 1-4), e adverte sobre os perigos dos casamentos mistos levarem à idolatria. Em

\footnotetext{
${ }^{40}$ GUTHRIE, George H. Hebrews. The NVI Application Commentary. Grand Rapids: Zondervan, 1998. p. 435; LOPES, Hernandes Dias. Hebreus: a superioridade de Cristo. Comentários expositivos Hagnos. São Paulo: Hagnos, 2018. p. 298.

41 ROBERTS, Alexander; DONALDSON, James; COXE, A. Cleveland. (Ed.). The Ante-Nicene Fathers: translations of the writings of the Fathers down to A.D. 325. Vol X. Oak Harbor: Logos Research Systems, 1997. p. 277.

42 A data de criação das Constituições é incerta. Estima-se que seja do século III ou IV.

43 ROBERTS; DONALDSON; COXE, Vol VII, 1997, p. 435.

44 WHITLARK, 2014, p. 59-61.
} 
Hebreus, a imoralidade sexual e os casamentos mistos também poderiam estar relacionados às tentações de uma sociedade imperial idólatra.

No império, apesar do esforço inicial de Augusto César para moralizar o casamento, a atividade sexual crescia para além dos limites do casamento legal, e a licenciosidade se normalizava. Além disso, as leis a respeito do adultério concediam tratamento desigual a homens e mulheres, privilegiando os homens. ${ }^{45}$ É nesse ambiente que os cristãos, homens e mulheres ("entre todos", sem distinção de gênero), são desafiados a viver uma ética sexual radicalmente diferente. E o fizeram de forma tão vigorosa que no século IV o imperador Constantino "revolucionou a visão estatal do casamento, a fim de colocá-lo mais de acordo com as ideias cristãs". ${ }^{46}$ Edward Gibbon afirma em seu clássico História do Declínio e Queda do Império Romano que "a dignidade do casamento foi restaurada pelos cristãos". ${ }^{47}$

Em $\mathrm{Hb}$ 13.5, os cristãos são advertidos contra a avareza, a viver com contentamento: "Seja a vossa vida sem avareza [aphilargyros, palavra que literalmente quer dizer 'sem amor ao dinheiro']". A avareza também é identificada como idolatria no Novo Testamento $(\mathrm{Cl}$ 3.5), e Mt 6.24 opõe Deus e Mamom. Se no império romano os cristãos poderiam facilmente se deparar com as tentações relacionadas à riqueza e ao status, ${ }^{48}$ hoje esse alerta de Hebreus pode ser bem aplicado ao materialismo, ao consumismo que deteriora as relações sociais.

Os cristãos tiveram sua propriedade privada confiscada pelo estado ( $\mathrm{Hb} 10.34)$. $\mathrm{O}$ confisco dos seus bens foi encarado com resiliência, pois sabiam que possuíam bens superiores e permanentes. Até o Édito de Milão (313 d.C.), quando as perseguições aos cristãos foram abolidas por Constantino, o judaísmo era a única religio licita (religião legal) no império romano além da própria religião romana. ${ }^{49}$

Após a destruição do Templo em 70 d.C., os judeus (cristãos incluídos) tinham que pagar o imposto Fiscus Judaicus, quando o imperador Vespasiano exigiu que todo o dinheiro antes usado na manutenção do extinto Templo de Jerusalém fosse agora destinado à reconstrução e posterior manutenção do Templo de Júpiter Capitolino em Roma. ${ }^{50}$ No entanto, mesmo sendo taxado, o judaísmo não perdeu o seu status de religio licita no império romano, mas isso não ocorreu com o cristianismo, que só se tornou religio licita em 313 d.C. ${ }^{51}$

\footnotetext{
45 EDWARDS, Catherine. The Politics of Immorality in Ancient Rome. Cambridge: Cambridge University Press, 2002. p. 35-38.

46 SCHMIDT, Alvin J. How Christianity Changed the World. Grand Rapids: Zondervan, 2004. p. 85.

${ }^{47}$ GIBBON, Edward. The History of the Decline and Fall of the Roman Empire. Vol 2. London: Penguin Books, 1994. p. 813.

48 WHITLARK, 2014, p. 56-59.

49 CAHNMAN, Werner Jacob. Jews and Gentiles: A Historical Sociology of Their Relations. New Brunswick: Transaction Publishers, 2004. p. 15.

50 Sobre as conseqüências do Fiscus Judaicus sobre a comunidade cristã primitiva, ver HEEMSTRA, Marius. The Fiscus Judaicus and the Parting of the Ways. Tübingen: Mohr Siebeck, 2010.

51 BROWN, Raymond E.; MEIER, John P. Antioch and Rome: New Testament Cradles of Catholic Christianity. Mahwah: Paulist Press, 1982. p. 95. GOODMAN, Martin. Diaspora Reactions to the Destruction of the Temple. In: DUNN, James D. G. (ed.) Jews and Christians: The Parting of the Ways, A.D. 70 to 135. Grand Rapids: Eerdmans, 1999. p. 31.
} 
Ao distanciar-se do judaísmo, o cristianismo foi considerada religio illicita (religião ilegal) e a perseguição se intensificou.

Em suma, como o próprio autor de Hebreus, o cristão deve viver condignamente (kalōs) em todas as coisas. ( $\mathrm{Hb}$ 13.18). A expressão grega traz a ideia de viver honestamente, de uma forma boa, corretamente, sem dar ensejo a acusações, com a consciência limpa, em todas as áreas da vida.

Porém, apesar de fazerem parte de uma religião ilegal, um grupo à margem da lei, os cristãos eram bons cidadãos e contavam "com a simpatia de todo o povo" (At 2.47), segundo testemunhos dos primeiros séculos. Uma carta do século II mostra a curiosidade de um pagão chamado Diogneto diante do crescimento do cristianismo no Império Romano. A resposta veio de um anônimo, e incluía a seguinte descrição:

Eles não se distinguem dos outros homens nem por país, nem língua, nem pelos costumes que observam. [...] Eles moram em seus próprios países, mas como peregrinos. [...] Cada terra estrangeira é para eles como seu país de origem, e sua terra natal é como uma terra de estrangeiros. [...] Eles passam seus dias na terra, mas são cidadãos do céu. Obedecem às leis estabelecidas, e ao mesmo tempo vão além das leis em suas vidas. Eles são difamados, e ainda assim são justificados; eles são injuriados, e abençoam; eles são insultados, e retribuem o insulto com respeito; eles fazem o bem, mas são punidos como malfeitores. Quando punidos, alegram-se, como se estivessem recebendo vida; eles são atacados pelos judeus como estrangeiros, e são perseguidos pelos gregos; No entanto, aqueles que os odeiam são incapazes de atribuir qualquer razão para o ódio. ${ }^{52}$

Aristides de Atenas (século II) também descreveu os cristãos como pessoas que vivem "na esperança e expectativa do mundo que há de vir", que "não dão falso testemunho, [...] e sempre que eles são os juízes, eles que julgam retamente" ${ }^{53}$

Na descrição de Aristides, os cristãos apaziguavam seus opressores, tornando-os seus amigos, e faziam o bem aos seus inimigos. Com impressionantes palavras, ele descreve o tipo de comunidade fraterna que os cristãos formavam:

A falsidade não se encontra entre eles; e eles amam uns aos outros, e das viúvas eles não afastam sua estima; e eles libertam o órfão daquele que o trata com dureza. $\mathrm{O}$ que tem dá àquele que não tem, sem contar vantagem. E quando veem um estranho, eles o levam para as suas casas e se alegrar com ele como se fosse um irmão próximo; pois não lhes chamam irmãos segundo a carne, mas irmãos segundo o espírito e em Deus. [...] E se ouvem que um deles está preso ou que sofre por causa do nome do seu Messias, todos eles ansiosamente ministram à sua necessidade, e se é possível resgatá-lo, eles o libertam. E se houver entre eles algum que é pobre e necessitado, e se eles não têm comida de reserva, eles jejuam dois ou três dias, a fim de suprir ao necessitado em sua falta de alimentos. ${ }^{54}$

\footnotetext{
52 Carta de 'Mathetes' a Diogneto", capítulo 5. Disponível em: <http:/ / www.earlychristianwritings.com/text/diognetus-lightfoot.html>. Acesso em: 19 jul. 2016.

53 ROBERTS; DONALDSON; COXE, Vol X, 1997, p. 277.

54 ROBERTS; DONALDSON; COXE, Vol X, 1997, p. 277.
} 


\section{A lealdade cristã radical}

Em Hebreus, os cristãos são lembrados do período inicial de sua caminhada, "quando suportaram muita luta e muito sofrimento" (Hb 10.32). O caminho mais fácil e suave geralmente não é o caminho alinhado aos princípios de Cristo, pois "todos quantos querem viver piedosamente em Cristo Jesus serão perseguidos" (2Tm 3.12).

O Autor afirma que os cristãos "foram expostos [theatrizō, como espetáculo] a insultos [oneidismos, acusação, difamação] e tribulações [thlîpsis, literalmente, 'pressão']; em outras ocasiões fizeram-se solidários com os que assim foram tratados" (Hb 10.33). Esse trecho não se refere às tribulações naturais da existência, mas a justaposição dessas expressões gregas dá uma conotação de opressão deliberada, perseguição propositalmente provocada, um espetáculo planejado. Mesmo sob perseguição, há um engajamento cristão no apoio solidário aos que sofrem perseguição por questões religiosas ou de consciência.

A lembrança do martírio ${ }^{55}$ e da possibilidade de "resistir até o sangue" ( $\left.\mathrm{Hb} 12.4\right)$ revela que a mensagem de Hebreus não é conformista diante da injustiça estatal. Hb 12.4 diz que aqueles cristãos não tinham "resistido até ao sangue", e parece que o Autor tem uma expectativa de que isso aconteça em breve. No entanto, há a instrução "segui a paz [eirēnēn diwkete] com todos", literalmente, "persigam a paz", ou "corram atrás da paz", uma postura ativa em busca da paz ( $\mathrm{Hb} 12.14)$. O uso da expressão sugere mais que um pacifismo passivo, ou a não belicosidade desde que não desafiado, mas buscar ativamente a harmonia, o entendimento, sem violência. É a busca da paz oposta à espada (Mt 10.34), oposta à divisão e à desunião (Lc 12.51). A única perseguição promovida por cristãos em Hebreus é a busca da paz.

A lembrança do martírio no mesmo contexto que incentiva a busca da paz com todos leva à seguinte conclusão: o cristão fica desobrigado a obedecer a um governo que desconsiderou a designação divina da sua função (Rm 13.3). Quando uma prática ou ordem governamental entra em conflito com uma clara ordem de Deus, não há mais como seguir a paz com todos, e cumpre ao cristão desobedecer a tal governo naquele ponto. Assim sendo, no contexto do culto ao imperador, os cristãos não buscaram a paz com Roma por meio de concessões de princípios - foram martirizados por não se submeterem ao poder de César e não reconhecerem outro Senhor além de Jesus. Quando o Estado e a política adquirem contornos messiânicos mas com práticas opressoras, Hebreus lembra que a lealdade do cristão, assim como a sua esperança, deve permanecer em Jesus Cristo.

\section{Considerações finais}

Há uma tensão em Hebreus. Curiosamente, em Hb 13.12-14, o mesmo povo que aguarda uma cidade é convidado a sair em direção a Jesus, "fora do arraial, levando o seu

\footnotetext{
55 Apesar de citar os mártires do passado, Hebreus não menciona nenhuma morte relacionada aos destinatários. Aparentemente, a perseguição enfrentada por essa comunidade ainda não tinha chegado a esse ponto.
} 
vitupério" (Hb 13.13). O termo arraial (parembolē) evoca a imagem de um acampamento fortificado, uma base de guerra que abriga um exército (como em $\mathrm{Hb}$ 11.34). O povo que busca a cidade celestial precisa sair desse arraial. Mas esse não é um chamado para alienarse social e politicamente, e sim para deixar a segurança terrena prometida pelos poderes políticos, e aceitar a vida de peregrino na terra, que inclui sofrer como Cristo.

As esperanças e aspirações dos cristãos não estão relacionadas com nenhuma cidade terrestre nem com nenhum sistema político terreno. Os cristãos não têm nada a ver com a mentalidade de dentro do arraial, de dentro da fortaleza, da Pax Romana. Por pertencerem à cidade de Deus que há de vir, eles estão buscando essa cidade fora dos muros, desprotegidos e cheios de expectativas escatológicas, ${ }^{56}$ uma esperança escatológica engajada e com deveres sociais (como resume $\mathrm{Hb} 13$ ).

Hebreus nos avisa que esperamos novos céus e nova terra, fala da pátria celestial, da cidade celestial, mas não ensina o isolamento ou a alienação, e sim um engajamento. Há uma tensão entre aguardar a cidade celestial e os deveres sociais. E essa tensão é saudável, pois, como destacou Freston, o cultivo da espiritualidade, a vida devocional, é a única coisa que pode impedir que o profetismo cristão se degenere em mera revolta. ${ }^{57}$

O seguidor de Cristo luta por um sistema mais justo, com leis mais justas, mas sem falsas expectativas de transformar o velho homem à parte da graça de Deus, pois a salvação vem por meio de Cristo ( $\mathrm{Hb} 5.9 ; 7.25 ; 9.28)$. Em suma, a leitura política de Hebreus revela que qualquer mobilização ou ação política cristã deve começar de joelhos diante de Cristo. E, em Hebreus, essa ação cristã será motivada, e não distraída ou sufocada, pela esperança escatológica.

\section{Referências}

AITKEN, Ellen Bradshaw. Portraying the Temple in Stone and Text: The Arch of Titus and the Epistle to the Hebrews. In GELARDINI, Gabriella (Ed.). Hebrews: Contemporary Methods. New Insights. Biblical Interpretation Series, vol 75. Boston: Brill, 2005.

BEALE, Gregory K.; CARSON, D. A. Comentário do uso do Antigo Testamento no Novo Testamento. São Paulo: Vida Nova, 2014.

BROWN, Raymond E.; MEIER, John P. Antioch and Rome: New Testament Cradles of Catholic Christianity. Mahwah: Paulist Press, 1982.

CAHNMAN, Werner Jacob. Jews and Gentiles: A Historical Sociology of Their Relations. New Brunswick: Transaction Publishers, 2004.

CALVINO, Juan. Epístola a los Hebreos. Grand Rapids: SLC, 1977.

\footnotetext{
56 WENGST, 1991, p. 142.

57 FRESTON, Paul. A reforma da igreja e a presença política: irmãs gêmeas. Disponível em: <http://www.ultimato.com.br/revista/artigos/322/a-reforma-da-igreja-e-a-presenca-politica-irmasgemeas>. Acesso em: 19 jul. 2016.
} 
Carta de 'Mathetes' a Diogneto", capítulo 5. Disponível em: <http://www.earlychristianwritings.com/text/diognetus-lightfoot.html>. Acesso em: 19 jul. 2016.

CROSSAN, John Dominic. O nascimento do cristianismo: o que aconteceu nos anos que se seguiram à execução de Jesus. São Paulo: Paulinas, 2004.

DE SILVA, David A. Perseverance in Gratitude: A Socio-Rhetorical Commentary on the Epistle to the Hebrews. Grand Rapids: Eerdmans, 2000.

DOCHERTY, Susan. The use of the Old Testament in Hebrews: a case study in early Jewish Bible interpretation. Tübingen: Mohr Siebeck, 2009.

DOOYEWEERD, Herman. Raízes da cultura ocidental: as opções cristã, secular e pagã. São Paulo: Cultura Cristã, 2015.

EDWARDS, Catherine. The Politics of Immorality in Ancient Rome. Cambridge: Cambridge University Press, 2002.

FERREIRA, Franklin. Contra a idolatria do Estado: o papel do cristão na política. São Paulo: Vida Nova, 2016.

FRESTON, Paul. A reforma da igreja e a presença política: irmãs gêmeas. Disponível em: <http:/ / www.ultimato.com.br/revista/artigos/322/a-reforma-da-igreja-e-a-presencapolitica-irmas-gemeas>. Acesso em: 19 jul. 2016.

GIBBON, Edward. The History of the Decline and Fall of the Roman Empire. 3 Vols. London: Penguin Books, 1994.

GOODMAN, Martin. Diaspora Reactions to the Destruction of the Temple. In: DUNN, James D. G. (ed.) Jews and Christians: The Parting of the Ways, A.D. 70 to 135. Grand Rapids: Eerdmans, 1999.

GUTHRIE, Donald. Hebreus: introdução e comentário. Série Cultura Bíblica. São Paulo: Vida Nova e Mundo Cristão, 1984.

GUTHRIE, George H. Hebrews. The NVI Application Commentary. Grand Rapids: Zondervan, 1998.

HEEMSTRA, Marius. The Fiscus Judaicus and the Parting of the Ways. Tübingen: Mohr Siebeck, 2010.

HORSLEY, Richard A. Paulo e o império: religião e poder na sociedade imperial romana. São Paulo, SP: Paulus, 2004.

. O reino de Deus e a nova desordem mundial. São Paulo: Paulus, 2004.

JEWETT, Robert. Letter to Pilgrims: A Commentary on the Epistle to the Hebrews. New York: Pilgrim, 1981.

KELLER, Timothy. Counterfeit Gods: The Empty Promises of Money, Sex, and Power, and the Only Hope That Matters. New York: Dutton, 2009.

KISTEMAKER, Simon J. Comentario al Nuevo Testamento. Grand Rapids: Libros Desafío, 1991.

KOESTER, Craig R. Hebrews: A New Translation with Introduction and Commentary. New York: Doubleday, 2001.

KOYZIS, David. Visões e Ilusões Políticas. São Paulo: Vida Nova, 2014. 
LOPES, Hernandes Dias. Hebreus: a superioridade de Cristo. Comentários expositivos Hagnos. São Paulo: Hagnos, 2018.

MESTERS, Carlos. Los Profetas Juan y Jesús y otros líderes populares de aquella época. Revista de Interpretación Bíblica Latino-Americana, San José, n. 1, (p. 45-52), 1988.

NEWTON, Bert. Subversive Wisdom: Sociopolitical Dimensions of John's Gospel. Eugene: Wipf \& Stock, 2012.

PUNT, Jeremy. The Letter to the Hebrews. In: SEGOVIA, Ferdinand; SUGIRTHARAJAH, Sharada. (eds.). Postcolonial Commentary on the New Testament Writings. New York: Continuum, 2007.

ROBERTS, Alexander; DONALDSON, James; COXE, A. Cleveland. (eds.). The Ante-Nicene Fathers: translations of the writings of the Fathers down to A.D. 325.8 vols. Oak Harbor: Logos Research Systems, 1997.

RÜPKE, Jörg. Starting sacrifice in the beyond Flavian innovations in the concept of priesthood and their repercussions in the treatise "To the Hebrews". Revue de l'histoire des religions, vol. 229, 2012, p. 5-30. Disponível em: <https://rhr.revues.org/7831\#text>. Acesso em: 09 set. 2016.

SAVELLE, Max. História da civilização mundial: as primeiras culturas humanas. Belo Horizonte: Itatiaia, 1971.

SCHMIDT, Alvin J. How Christianity Changed the World. Grand Rapids: Zondervan, 2004.

SENNETT, Richard. Carne e pedra: o corpo e a cidade na civilização ocidental. Rio de Janeiro: Record, 1997.

WENGST, Klaus. Pax romana: pretensão e realidade. São Paulo: Edições Paulinas, 1991.

WHITLARK, Jason A. Resisting Empire: rethinking the purpose of the Letter to "the Hebrews". New York: Bloomsbury T\&T Clark, 2014.

WILSON, R. McL. Hebrews. The New Century Bible Commentary. Grand Rapids: Eerdmans, 1987. 